\title{
JUURNAL_RU
}

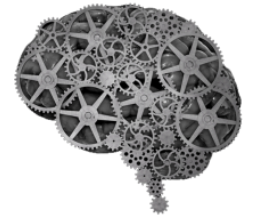

COMPANY GROUP "INTELLEKT"

\author{
Морозова К. С. \\ Самарский Государственный Архитектурно-Строительный Университет \\ г. Самара, Россия
}

doi: 10.18411/1j2016-5-3-12

\section{Поддомен или поддиректория - влияние на продвижение сайта}

HTTPS - сайт с шифрованием и защищенной передачей данных, в то время как НТТР протокол не защищен. Сразу возникает мысль, что предпочтительней выбирать первый вариант при программировании своего сайта, но если разобраться, то станет ясно, что не все так просто. В некоторых случаях второй вариант с незащищенным протоколом будет предпочтительней.

Итак, каковы минусы перехода на сайт с шифрованием?

Bo-первых, SSL сертификат обойдется вам в кругленькую сумму, которую необходимо платить ежегодно. Если ваш сайт не связан с финансами и не действует как интернет-магазин, то смысла в сертификате нет.

Bo-вторых, HTTP и HTTPS - две разные версии сайта, поэтому при программировании второй версии сайт может существенно измениться.

B-третьих, страдает органический трафик при переходе на защищенную версию сайта. То есть, поток посетителей может стать меньше, что ударит по популярности сайта и его расположению в поисковой системе.

Конечно, это не значит, что SSL сертификат никому не нужен. Задуматься о его покупке стоит в первую очередь тем, кто собирается покупать домен и работать с валютой на сайте, к примеру, открывать интернет-магазин. В таком случае целесообразнее всего будет потратить деньги на HTTPS версию.

Как показывает опыт, со временем все сайты перейдут на SSL сертификат, что является вполне хорошей идеей, которую просто нужно немного доработать и сделать более доступной. 


\section{Литература}

1. Тимофеев А.В., Морозова К.С. Поддомен или поддиректория - влияние на продвижение сайта. Сборник международной научной конференции SCIENCE - 2016г. 